\title{
SOCIAL ASPECTS OF EPILEPSY IN CHILDHOOD
}

\author{
John Beasley, M.B., B.S., D.P.H. \\ Senior School Medical Officer, Reading C.B., Late School Medical Officer, Warwickshire
}

IT is impossible to deal with every social aspect of epilepsy in childhood: instead I shall try to discuss a few points which may prove to be of consequence.

An important component of disease is the pressure exerted on the patient by the society in which he lives, and the patient's reaction to that pressure. I should like to read to you a passage from E. M. Btidge's book on epilepsy in childhood.

\begin{abstract}
'The child has been happy and in good health when suddenly a strange, terrifying feeling comes over him, the world goes black and he awakes to find himself in bed, the family excited and worried, and the doctor beside him. Big words are spoken, medicine prescribed, and he is made to stay in bed for the rest of the day with a dull headache and nothing to do. What happened, why all the excitement? He does not know, and something in the atmosphere gives him the feeling that he should not ask. The episode is never mentioned again.... Every day he is asked how he feels. . . . It does come again with the same feeling. He tries to run to mother, tries to call for help, but the awful blackness is upon him. Again he wakes to family excitement, but this time the doctor is sewing up a cut on his forehead, or he finds his tongue is very sore. ... He hopes he will never get another one. But others follow, and he has them with increasing terror at the onset, and in between he is in more and more continual dread of them. Life becomes centred around these miserable spells, visits to doctors and hospitals, needles, medicines-everything that a boy wants to avoid. Furthermore, he is no longer allowed to go to school or to ride his bicycle. Why? A silly excuse for an answer. All the other children do, why shouldn't I? She doesn't like me. The other children act strangely towards him now. . . '
\end{abstract}

Perhaps this is a bit overdrawn. Perhaps all this doesn't happen always-but it is the sort of thing that may happen.

The child's society alters as he grows. First, and most important, there is the family. Of all childhood handicaps, epilepsy seems to evoke the most intense parental responses; the most extreme have been named 'hyperpædophilia' by Dr. Ounsted at Oxford. In this condition the parents cannot tear themselves away from their afflicted child. They cannot allow him, or her, out of their sight for a moment-even to go to school without them. So great is this attachment that they may drive themselves, and the ch ${ }_{d}$, to distraction. I suppose that it is produced b a compound of the fear created by the word 'epilepsy' (so many people class it with Frankenstein, with vampire bats and horror films), ând the fear that the child may die in an attack if the parents leave him. Superimposed, of course, may be feelings of guilt, recriminations, anguished ignorance, and so on. I am sure that it is vêry important to counsel parents, and I think that one has to talk to them until they themselpes begin to ask the questions.

The second society which the child entênsois that of the school. Nowadays this is sefom hostile: most children love going to sefoll. The vast majority of epileptic children are successful in ordinary schools. Recently, I was ableoto 'follow up' all the children with fits seen कैy Dr. MacGregor in South Warwickshire durmg ten years. Out of 269 children old enough to $\overrightarrow{\mathrm{g}} 0$ to school, only two needed to be educated at a special school for epileptic children. There were others who needed to be educated in schools for the educationally subnormal, but because of subnormality, not because of the fits. Out of old enough for senior schools, nine are known to have attained grammar school places-a substantial proportion. However, no child with typieal centrencephalic epilepsy got to a grammar school. In these children petit mal attacks are frequent, and they break into the child's streatrm of thought, and into the progress of his learnizg. The teacher may not realize that the 'absencess' are happening. She cannot take care to see that the child catches up as she would after an obvi@is grand mal attack. This leads me to ask youcto tell the school doctor about these children. It does not mean that they will be brandedecor picked upon, but it does mean that the teacher will not be surprised by a sudden unexpected fit, and that the school doctor will be able to discuss management and any anxieties with the schol staff before a fit occurs.

The School Health Service and Handicappe्व 
Pupils Regulations define the epileptic pupils who require special schooling as:-'pupils who by reason of epilepsy cannot be educated under the normal regime of ordinary schools without detriment to themselves or other pupils'. I want to stress that there are very few pupils indeed who cannot be educated 'under the normal regime of ordinary schools'; that is, if there is no other serious coxistent handicap.

Currently there is a new expression in vogue, 'school leaving shock'. Undoubtedly children are exposed to considerable problems of adjustment when they start at school, and equally so when they leave to enter the wider world of employment. Many people are concerned about the introduction of handicapped children into industry. It has been suggested that, perhaps, there should be a pre-employment year; the child being released from school for a day or two each week to go to work. The Youth Employment Service is, of course, very helpful in the initial placing of the children. The length of follow-up varies from place to place. Industrial failures are those who do not settle, those who flit from job to job. The Youth Employment Service cannot supervise them indefinitely. They have left the School Health Service behind them. Perhaps the Welfare Department will help them-but there is a gap, and it comes at this critical time.

There are special facilities for children with serious continued disability. The Ministry of Labour administer a number of Industrial Rehabilitation Units (there is an excellent one in Coventry) where children who have left school can be assessed in a variety of work situations. Problems which arise can be minimized and, sometimes, the child may be taught a trade in the protected environment of a Government Training Centre.

The Ministry of Labour's Disablement Resettlement Officers say that finding jobs for epileptics is one of their most difficult problems. Reasons for failure being:-

I. The dislike shown by fellow workers for the interruption and upsets caused by seizures at work. (I think that an equally important cause of failure is that many of their fellows still regard fits with atavistic fear and abhorrence. One hears of epileptics who are so ashamed that they do not wait, but leave as soon as they feel that their secret is revealed.)
2. Too many jobs are thought to be unsuitable. Work involving climbing, fire, fast-moving machinery, and the handling of detonators may well be so. But this still leaves a great many other entirely suitable jobs in agriculture, upholstery, and clerical and domestic occupations.

My own feeling is that there are very few jobs which are impossible and, of course, each case has to be judged individually. A man who has only nocturnal fits can do almost any kind of work satisfactorily.

Lastly, I thought that I might say something about driving because every boy and most girls will want to drive if they can. There is plenty of evidence to suggest that many epileptics drive. Josephine Webb found five epileptics amongst 1,276 professional drivers examined at National Service medical boards. In 1956 Hierons reported a personal series of 28 drivers who had had fits which had caused a road accident. In $196 \mathrm{I}$ Phemister found 27 driving-licence holders among 60 men who had fits, but only one among 70 women. None of the drivers in his series admitted to any accident, which might be because concentration decreases the number of fits. Pond and Bidwell reported ig unrepentant drivers amongst 180 'epileptics' in 1960. Many epileptics are turned against society because they feel that it is unjust that they should not be allowed to drive. Because of this reaction I do not think that it is sensible to proscribe driving for all time. No epileptic should be expected to feel that he is debarred for life.

The Road Traffic Act, 1930, lays down that an applicant for a licence must state if he suffers from epilepsy. Some states in America have a medical panel who may grant licences to those who they consider will remain free from attacks. This seems to be successful. Similar panels have been set up in some places here. They might be empowered to compensate those whom they deny.

Because I am particularly interested in prevention I believe that parents should be counselled before their anxieties react on their children; that teachers should be advised before the unexpected fit causes a classroom sensation; that employment problems should be assessed before they arise; and that any restrictions on driving, for instance, should be explained and minimized before they become constraint.

\section{REFERENCES}

Bridge, E. M. (1949): Epilepsy and Convulsive Disorders in Childhood. New York, London: McGraw Hill. Hierons, R. (1956): The Epileptic Driver, Brit. med. F., i, 206

Phemister, J. C. (196r): Epilepsy and Car Driving, Lancet, i, 1276.

PoND, D. A., and Bidwell, B. (1960): A Survey of Epilepsy in 14 General Practices, Epilepsia, r, 285.

WEBB, J. (1955): Standards of Fitness among Drivers of Commercial Road Vehicles, Brit. med. $\mathcal{F}$., i, 5 I 5. 